\title{
Organizational Factors Affecting Knowledge Sharing Capabilities in E-government: An Empirical Study
}

\author{
Soonhee $\mathrm{Kim}^{1}$ and Hyangsoo Lee ${ }^{2}$ \\ ${ }^{1}$ Syracuse University, New York, USA \\ soonheekim@maxwell. syr.edu \\ ${ }^{2}$ National Computerization Agency, Seoul, Korea \\ lhs@nca.or.kr
}

\section{Introduction}

E-government, a concept that emerged in the late 1990s, is facing challenging opportunities for improving public service delivery to individual citizens. The Internet, the World Wide Web, and other digital tools are transforming the ways in which business, the public, and government communicate, and altering citizen demand for government service delivery $[6,32]$. Public expectations for fast and convenient service delivery and institutional needs for efficiency are motivating agencies to experiment with e-government ventures[4]. Modesitt[27] and Greeves[18] are among a growing number of researchers taking note of government use of the Internet, Geographic Information Systems (GIS), and Web technologies to establish external collaboration, civic engagement, networking, and customer service. E-government services are clearly expanding and will continue to do so; the speed at which the expansion occurs will be limited only by the speed at which technical and financial capacities evolve and organizational/managerial philosophies emerge.

There is an increasing emphasis on the importance of knowledge management beyond information system management in both the private and public sectors $[8,10$, $16,31,30,35]$. Specifically, the application of advanced information technology to public service has brought new attention to the ability of government agencies to coordinate and enable the creation, integration, management, sharing, and transfer of information within agencies and in governmental networks. The importance of knowledge sharing in e-government has been emphasized in public administration along with the emerging discourse of network governance and network management. However, despite considerable research emphasis on information management and egovernment, there has been little research pertaining to a systematic analysis of the organizational factors affecting knowledge sharing capabilities in the public sector.

The purpose of this paper is to analyze how organizational structure, culture, and information technology influence knowledge sharing capabilities in public organizations. To enhance our understanding of the organizational factors affecting knowledge management in public organizations, survey questionnaires were sent to employees in five national government agencies in South Korea to elicit their opinions on how organizational structure, culture, and information technology influence knowledge sharing capabilities. The five government agencies selected for this exploratory study have established knowledge management information systems 
as well as information technology infrastructures for e-government services. According to a United Nation (UN) survey of e-government projects in 2001, South Korea ranked 15th among 98 nations working to expand their e-government capacities [36]. This is an important trend in that country, since the percentage of South Korean citizens with Internet access has expanded from 6.8 in 1998 to 51.5 in 2001 [15]. Since 1987, the Korean government has established an information technology infrastructure that includes 3 national, 16 metropolitan and provincial, and 232 city, county, and district government networks. Following the development of this IT infrastructure, the South Korean legislature passed a 2001 law promoting the establishment of egovernment services.

The results from a multiple regression analysis of the collected data will be presented, followed by a discussion of the major findings and their implications for knowledge sharing capabilities in government. The paper concludes with several suggestions for improving knowledge management in e-government and future research.

\section{Literature Review and Research Model}

\subsection{Knowledge Sharing Capabilities and Organizational Factors}

Davenport and Prusak [10] define knowledge as a fluid mix of framed experience, values, contextual information, and expert insight that provides a framework for evaluating and incorporating new experiences and information. They note that in organization, knowledge often becomes embedded not only in documents but also in organizational routines, processes, practices, and norms. As knowledge is a central resource of government service, effective knowledge sharing in the public sector is a significant public management challenge for providing excellence in public service. Particularly, knowledge-sharing capabilities are considered key to the success of egovernment to meet the needs and demands of constituencies in all levels of government. The creation of knowledge sharing capabilities in public organizations requires dissemination of individual employees' work-related experiences and collaboration between individuals and between subsystems of the organization. In addition, collaboration with other agencies and stakeholders is the basis for improving knowledge sharing capabilities [14, 20], in the public sector. Several researchers [11, 17] suggest that combining or integrating knowledge in different parts of the organization reduces redundancy, enhances consistent representation, and improves efficiency by eliminating excess volume.

This paper explores how three organizational dimensions as independent variables influence knowledge shaping capabilities in public organizations (see Figure 1). These three dimensions are organizational culture (visions and goals, trust, and social networks), organizational structure (centralization, formalization, and performancebased reward systems), and information technology (IT application, and end-user focus).

Organizational Culture: Scholars indicate that organizational culture is central to an organization's ability to manage its knowledge more effectively $[11,8,12]$. Three components of organizational culture receiving consistent attention related to 
effective knowledge management include clear organizational vision and goals [24, 21], trust [37, 29, 21] and social network [25, 29]. As noted by Leonard [24], an important component of culture is organizational vision. Several scholars also note that the overall vision generates a clear organizational purpose so that it can achieve its desired future goals [21]. Clear organizational vision and goals are also important to engender a sense of involvement and contribution among employees [9, 29]. Along with clear organizational vision and goals, Von Krogh [37] suggests that trust and openness in organizational culture promote employees' active knowledge management behaviors. Scholars and practitioners also indicate that communications, dialogue, and interaction between individuals or groups are important to support and to encourage employees' knowledge-related activities[25, 29] . Especially, formal and informal relationships and contacts are important for sharing different perspectives and knowledge in organizations [29]. In this study we explored how organizational culture, including visions and goals, trust, and social network affect employee's knowledge sharing capabilities.

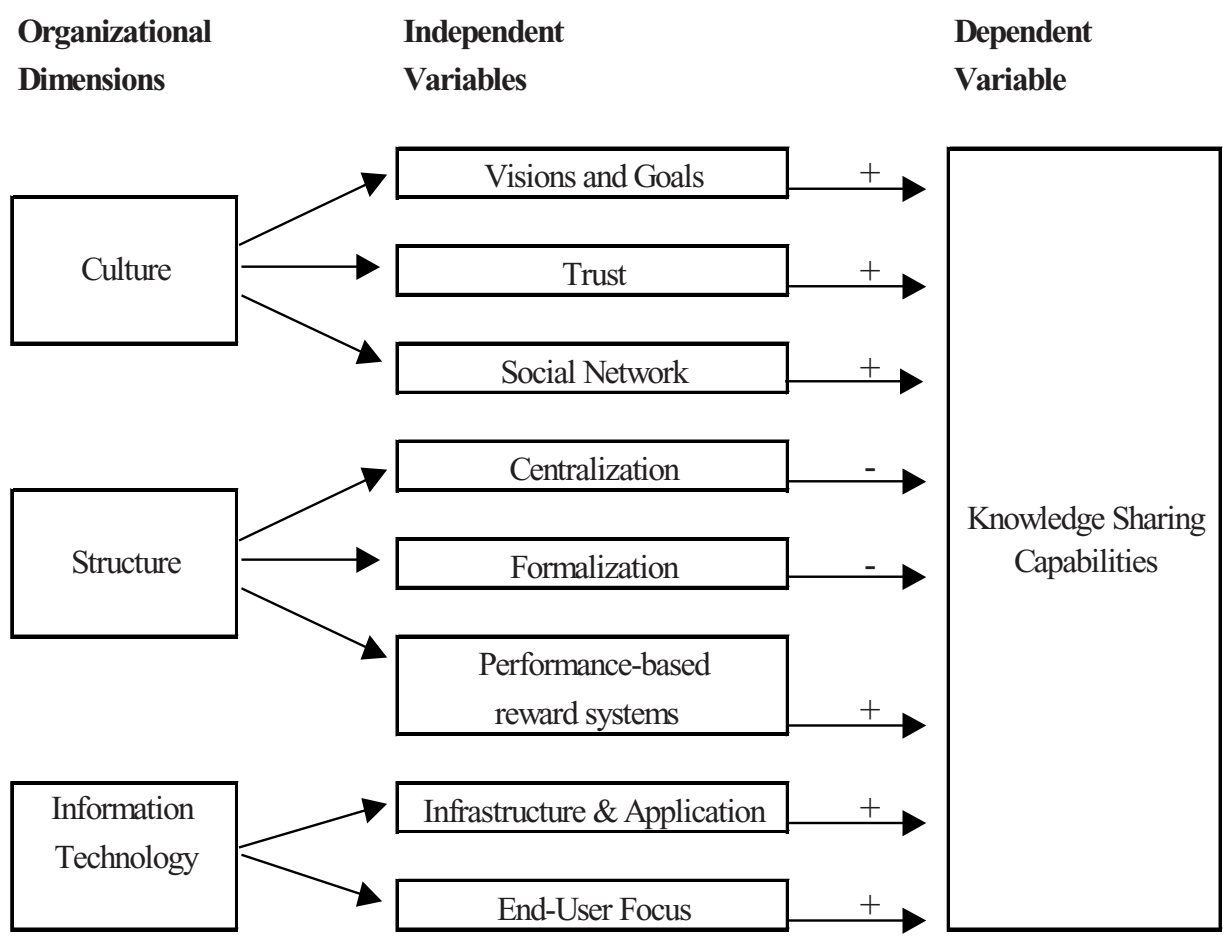

Fig. 1. Research Model 
Organizational Structure: The present study includes three variables of organizational structure dimension, including centralization, formalization, and performance based reward systems. Organizational structure has often had the unintended consequence of inhibiting collaboration and sharing of knowledge across internal organizational boundaries[29]. Creed and Miles[7] also note that a hierarchical structure in government limits active knowledge sharing activities and communication between employees or between employees and supervisors. O'Dell and Grayson [29] agree that organizational structures should be designed for flexibility (as opposed to rigidity) to encourage sharing and collaboration across boundaries within the organization and across the supply chain. However, this effect can also be achieved by maintaining the formal hierarchical structure while adding the dimension of flexibility [28]. Nonaka and Takeuchi [28] indicate that a combination of a formal organizational structure and a non-hierarchical, self-organizing organizational structure would improve knowledge creation and sharing capabilities. Another important variable related to organizational structure dimension in which this study is interested is a performance-based reward system. Leonard [24] argues that organizational reward systems can determine how knowledge is accessed and how it flows in organizations. Several scholars note that incentive systems should be in place to promote employees' motivation for taking the time to generate new knowledge (i.e., learn), share their knowledge, and help others outside their own divisions or functions [1, 29].

Information Technology: Scholars also emphasize information technology infrastructure as an element crucial to the linkage of information and knowledge integration in organizations $[2,13,33]$. In order to build knowledge sharing capabilities, the organization must develop a comprehensive infrastructure that facilitates the various types of knowledge and communication. Several dimensions of the technology infrastructure analyzed by Grant [17] and Leonard [24] include business intelligence, collaboration, distributed learning, knowledge discovery, knowledge mapping, opportunity generation, and security. Specifically, Leonard [24] notes that knowledge mapping technologies allow an organization to track its sources of internal and external knowledge so that individuals in need of a specific type of knowledge know where it resides. As the five government agencies selected for this exploratory study have established knowledge management information systems and information technology infrastructures for e-government services, the present study analyzed how employees' use and application of information systems affect their knowledge-sharing capabilities. Another important component of information technology related to knowledge sharing is the level of end-user focus of information system development. In order to improve knowledge management capabilities in organizations, information systems and software should be developed to promote easy use and application by end-users $[23,3]$.

\section{Research Method}

\subsection{Sample Selection and Survey Administration}

The study incorporated data from a 2003 survey of public employees working in five national government agencies in South Korea: Ministry of Government Affairs and 
Administration, Ministry of Information and Telecommunication, Ministry of Justice, Ministry of Science and Technology, and Ministry of Culture and Tourism. A reason for the selection of these five agencies was that these government agencies have adopted knowledge management information systems and information technology infrastructures for e-government services. All of the survey respondents indicated that their agency has established Internet based e-government services, Intranet, electronic data management systems, and knowledge management information systems. The survey sample was constructed from individual employee directories. Copies of the survey were distributed to 200 selected department employees (40 survey copies for each agency). One follow-up survey was also sent. From the total adjusted sample of 200 survey questionnaires, 165 were returned; 3 of these were considered invalid because they were incomplete. Hence, the final number of usable questionnaires was $162-$ a response rate of 81 percent.

\subsection{Survey Measures and Items}

The self-administered survey instrument was designed to elicit information on employee perceptions of organizational culture, structure, information technology, and knowledge sharing capabilities, as well as demographic information. In order to measure knowledge sharing capabilities, three sub-dimensions of knowledge sharing were developed [31, 16] : 1) knowledge sharing between employees; 2) employees' easy access to other divisions' documents, information and knowledge; and 3) knowledge sharing between teams and groups. To assess the validity of our research model, measures of the three sub-dimensions of organizational structure (centralization, formalization, and reward systems), three sub-dimensions of culture (visions and goals, trust, and social network), and two sub-dimensions of information technology (infrastructure and application, and end-user focus) were developed (see Appendix). Multiple-item measures were used for all of the variables to improve the reliability and validity of the measures. These measures are largely derived from the literature on knowledge management. In addition, responses were recorded using a seven-point Likert scale (ranging from $1=$ strongly disagree to $7=$ strongly agree).

Coefficient alpha reliability estimates for all of the variables were arranged from .75 (formalization) to .93 (visions and objectives). All of the coefficient alpha reliability estimates are included in Table 1 below. A factor analysis indicated that the items designed to measure the three organization dimensions and knowledge sharing capabilities loaded on four separate factors: organizational culture, structure, information technology, and knowledge sharing capabilities. The factor loadings of all of these items support the use of these items as indicators of the underlying constructs they were designed to measure. The three demographic information questions included in the survey were years of work, position, and education.

\section{Findings}

The majority of respondents $(68.5 \%)$ worked in administration positions. There were 32 employees (19.8\%) reporting themselves as information technology professionals. Only 22 respondents $(13.6 \%)$ were female. In terms of age, the sample 
ranged from the twenties to over fifty, but more than thirty percent of respondents were over forty years old $(33.3 \%)$. The distribution for work experience in the current department was: less than 5 year: $15.5 \%$; 5-10 years: $22.3 \%$; 11-15 years: $32 \%$; 16-20 years: $16 \%$; and 21 years or more: $14.2 \%$. The majority of respondents reported having a college degree, with 18.5 percent holding graduate or professional degrees. Position levels ranged as follows: lower level (Grade 9-8): $13.5 \%$; middle level (Grade 7-6): $51.8 \%$; and higher level (Grade 5-4): $34.6 \%$.

Table 1. Descriptive Statistics, Reliabilities, and Correlations

\begin{tabular}{|c|c|c|c|c|c|c|c|c|c|c|c|}
\hline & $\begin{array}{l}\text { Mean } \\
\text { (s.d) }\end{array}$ & 1 & 2 & 3 & 4 & 5 & 6 & 7 & 8 & 9 & 10 \\
\hline $\begin{array}{l}\text { 1. Visions \& } \\
\text { goals }\end{array}$ & $\begin{array}{l}4.50 \\
(1.20)\end{array}$ & 1.0 & $(.93)$ & & & & & & & & \\
\hline 2. Trust & $\begin{array}{l}4.95 \\
(1.0)\end{array}$ & $.48 * *$ & 1.0 & $(.81)$ & & & & & & & \\
\hline $\begin{array}{l}\text { 3. Social net- } \\
\text { work }\end{array}$ & $\begin{array}{l}3.93 \\
(1.11)\end{array}$ & $.46^{* *}$ & $.46^{* *}$ & 1.0 & $(.85)$ & & & & & & \\
\hline $\begin{array}{l}\text { 4. Centraliza- } \\
\text { tion }\end{array}$ & $\begin{array}{l}3.93 \\
(1.21)\end{array}$ & $-.41^{* *}$ & $-.32 * *$ & $-.28 * *$ & 1.0 & $(.85)$ & & & & & \\
\hline 5. Formalization & $\begin{array}{l}4.51 \\
(0.94)\end{array}$ & -.03 & -.04 & .09 & $.45^{* *}$ & 1.0 & $(.75)$ & & & & \\
\hline $\begin{array}{l}\text { 6. Performance } \\
\text { based reward } \\
\text { systems }\end{array}$ & $\begin{array}{l}3.30 \\
(0.87)\end{array}$ & $.52 * *$ & $.26^{* *}$ & $.50 * *$ & $-.30 * *$ & -.05 & 1.0 & $(.83)$ & & & \\
\hline $\begin{array}{l}\text { 7. IT } \\
\text { Infrastructure } \\
\text { application }\end{array}$ & $\begin{array}{l}4.98 \\
(1.49)\end{array}$ & $.18 *$ & $.28 * *$ & $.21 * *$ & -.15 & .04 & .04 & 1.0 & $(.86)$ & & \\
\hline $\begin{array}{l}\text { 8. End-user } \\
\text { focus }\end{array}$ & $\begin{array}{l}4.53 \\
(1.11)\end{array}$ & $.37 * *$ & $.47 * *$ & $.45 * *$ & $-.25 * *$ & .14 & $.34 * *$ & $.36^{* *}$ & 1.0 & $(.82)$ & \\
\hline $\begin{array}{l}\text { 9. Knowledge } \\
\text { sharing capa- } \\
\text { bilities }\end{array}$ & $\begin{array}{l}3.82 \\
(1.20)\end{array}$ & $.32 * *$ & $.24 * *$ & $.45^{* *}$ & $-.30 * *$ & -.06 & $.43 * *$ & $.38 * *$ & $.40 * *$ & 1.0 & $(.89)$ \\
\hline
\end{tabular}

Descriptive statistics and correlation coefficients indicate that the majority of the zero-order correlations were statistically significant at $p<0.01$. All of the measures appeared to be relatively distinct; the largest correlation (between organizational visions, objectives, and performance-based reward systems) was .52. Mean scores for visions and objectives (4.50), trust (4.95), formality (4.51), technology infrastructure and application (4.98), and end-user focus (4.53) were relatively high, but scores for social networks (3.93), centralization (3.93), and performance based reward systems (3.30), and knowledge sharing capabilities (3.82) were relatively low.

\subsection{Multivariate Analysis}

Results from an ordinary-least square (OLS) multiple regression analysis appears in Table 2. The equation achieved statistical significance at the .001 level. Among the variables of organizational culture, the variable of social network was positively associated with high levels of knowledge sharing capabilities: the results showed that 
employees who perceived high degrees of social networks reported higher levels of knowledge sharing capabilities than employees who did not $(p<.01)$. Statistical support was also found for organizational structure dimension. Government employees who perceive a high level of performance-based reward systems are more likely to express higher levels of knowledge sharing capabilities $(p<.01)$. Moreover, the regression analysis results showed that employees who perceive a high level of information technology application are more likely to express their capabilities of knowledge sharing at a statistically significant level $(p<.001)$. However, end-user focus was not significantly associated with employees' knowledge sharing capabilities when three control variables were included in the regression model (Table 2).

The report provided no statistical support for some other variables. Clear visions, goals, and trust were not significantly associated with employees' knowledge sharing capabilities in this study. Nor were centralization and formalization significantly associated with knowledge sharing capabilities. Among the control variables, the data showed that the surveyed employees who had been working in their present departments for longer periods of time were more likely to express high levels of knowledge sharing capabilities (see Table 2).

\section{Implications and Future Research}

The results of this study evince that social networks, performance-based reward systems, and information technology application are all significant variables affecting knowledge sharing capabilities in e-government. The data strongly suggest that executive leaders, public managers, and managers of e-government need to acknowledge these factors when addressing the issues of effective knowledge management and capabilities of knowledge sharing for government service.

The findings also suggest several strategies for consideration by government agencies interested in enhancing employees' capabilities for knowledge sharing. The first consists of conducting employee assessments regarding internal and external social networks. The employee assessments should focus on communications, contacts, and interactions between employees and between work divisions and agencies. Performing such assessments can be a first step in giving employees the perception that their departments are interested in their network environment, informal networks, communication flow among teams, and access to information among divisions, all of which are significantly associated with knowledge sharing capabilities. Managers and supervisors can also develop a plan of action to improve knowledge sharing capabilities. For example, executive leaders and managers can develop incentive and reward systems for recognizing excellent knowledge sharing abilities of employees. Fair and objective performance-based reward systems may promote employees' motivation for taking the time to generate new knowledge, share their knowledge, and help others outside their own divisions or functions $[1,29]$.

The study results show that organizational investment on information technology infrastructure and knowledge management information systems is an important factor affecting knowledge sharing capabilities through employees' usage and application of these information systems. Accordingly, executive leaders and managers need to 
create workforce technology environments in which individual employees perceive a supportive interest in their knowledge sharing capabilities.

All of these suggestions for improving the knowledge sharing capabilities of employees in e-government require organization leaders to commit to promoting informal and formal networks and knowledge-oriented management practices. Especially considering the emergent emphasis on homeland security and e-government, agency leaders, IT managers, and human resource managers must collaboratively respond to fundamental environmental changes in order to encourage employees' commitment to knowledge sharing capabilities and organizational performance.

Table 2. Results of Regression Analysis

\begin{tabular}{|c|c|c|c|c|}
\hline $\begin{array}{c}\text { Organizational } \\
\text { Dimensions }\end{array}$ & Variables & $\begin{array}{c}\text { Regression } \\
\text { Coefficient }(\beta)\end{array}$ & $\begin{array}{c}\text { Standard } \\
\text { error }\end{array}$ & $t$ \\
\hline \multirow[t]{4}{*}{ Culture } & Visions \& goals & & & \\
\hline & & -.02 & .08 & -.30 \\
\hline & Trust & -.08 & .09 & -1.08 \\
\hline & Social network & $.23^{* *}$ & .08 & 2.80 \\
\hline \multirow{3}{*}{ Structure } & Centralization & -.07 & .08 & -.85 \\
\hline & Formalization & -.08 & .10 & -1.08 \\
\hline & $\begin{array}{l}\text { Performance based } \\
\text { reward systems }\end{array}$ & $.25^{* *}$ & .11 & 3.11 \\
\hline \multirow[t]{2}{*}{$\begin{array}{l}\text { Information Tech- } \\
\text { nology }\end{array}$} & $\begin{array}{l}\text { Infrastructure \& } \\
\text { application }\end{array}$ & $.27 * * *$ & .05 & 3.96 \\
\hline & End-user focus & .12 & .08 & 1.51 \\
\hline \multirow{5}{*}{$\begin{array}{l}\text { Demographic in- } \\
\text { formation }\end{array}$} & Years of work & $.17^{*}$ & .05 & 2.57 \\
\hline & Position & -.04 & .07 & -.63 \\
\hline & Education & .01 & .24 & .01 \\
\hline & $R^{2}$ & .471 & & \\
\hline & $\begin{array}{l}\text { Adjusted } R^{2} \\
\mathrm{~F}\end{array}$ & $\begin{array}{c}.374 \\
9.745^{* * *}\end{array}$ & & \\
\hline
\end{tabular}

$\mathrm{N}=162 ; * p<.05 ; * * p<.01 ; * * * p<.001$

An important implication of this study for future research is that researchers may wish to examine the variance of knowledge sharing capabilities in e-government in terms of social networks and performance-based reward systems. The findings of this study indicate that social networks and performance-based reward systems can be significant organizational factors affecting employees' knowledge sharing capacities. If some public organizations have established knowledge management information systems as well as information technology infrastructures and applications for egovernment services, researchers can focus on two independent variables of social networks and performance- based reward systems for explaining the variances of knowledge sharing capabilities among agencies. For example, a typology construction and analysis can be applicable to understand knowledge sharing capabilities in egovernment (see Table 3). 
Table 3. Knowledge Sharing Capabilities in Public Organizations (Social Networks and Reward Systems)

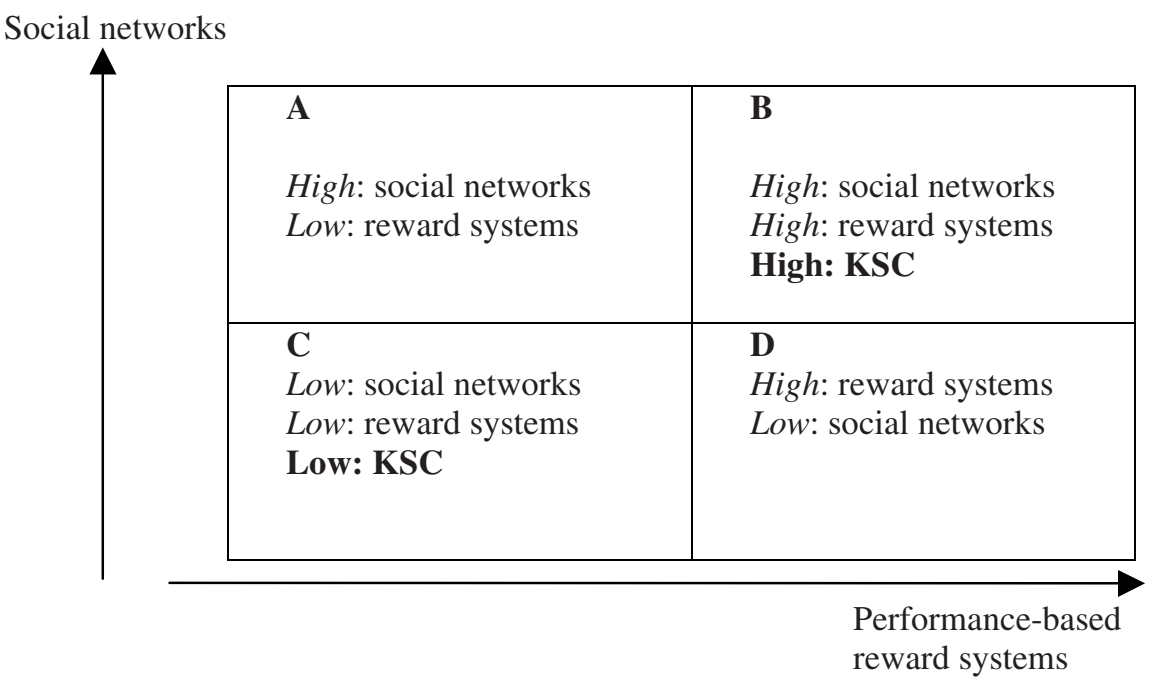

Table 3 summarizes the intersection of two variables for understanding different levels of knowledge sharing capabilities (KSC) in organizations: the degree of social networks and the level of performance-based reward systems. In this typology, all organizations in four cells are supposed to have established IT infrastructures and IT applications. Organizations in cell B of the table have a high degree of social networks among employees and a high level of performance-based reward systems; those in cell $\mathrm{C}$ are low on both. Those in cells A and D would be high on one and low on the other. Based on the finding of this study, organizations in cell B would have a higher degree of knowledge sharing capabilities than the other cells. Those in cell $\mathrm{C}$ have would have a lower degree of knowledge sharing capabilities than the other cells. Although those in cell $\mathrm{C}$ have established IT infrastructures and IT application, the low degree of social networks and the low level of performance-based reward systems negatively affect employees' knowledge sharing capabilities. Further empirical analysis of this typology may provide an appropriate device for understanding how organizational culture and organizational structure affect the level of knowledge sharing capabilities in e-government.

\section{Conclusion}

The associations among organizational culture, structure, information technology and public employees' knowledge sharing capabilities explored in this study can also be the subjects of research with other nations' public employees. An assessment of the validity of the findings presented in this paper would be especially valuable. Future projects should also focus on: a) associations among the level of e-government development, knowledge acquisition, knowledge preservation, and knowledge application 
beyond knowledge sharing capabilities; and b) comparative studies of private and public sector knowledge sharing capabilities.

Several limitations to this research should be noted. First, the measures used here were perceptual rather than objective; a more complete analysis would require additional data from interviews of employees and longitudinal studies of the dynamics and patterns of knowledge sharing capabilities through e-government transformation. Second, while the response rate for the survey was high, the sample size was small. In conclusion, the results suggest that organizational culture, structure, and information technology all exert significant forces on knowledge sharing capabilities among South Korean government employees. The findings imply a need for intensified organizational and managerial commitment to knowledge sharing capabilities through promoting informal and formal networks, reward systems for knowledge sharing abilities, and enhancing information technology as well as end-user support for government employees.

\section{References}

1. Argote, L., and D. Epple. 1990. Learning Curves In Manufacturing. Science 247(23): 920924.

2. Argyris, C., and D. Schon. 1978. Organizational Learning: A Theory of Action Approach. Reading, MA: Addison Wesley.

3. Branscomb, L. M. and J.C. Thomas. 1984. Ease of Use: A System Design Challenge. IBM Systems Journal (23): Pp.224-235.

4. Center for Technology in Government. 1999. Some Assembly Required: Building A Digital Government For The 21st Century. Report of a Multidisciplinary Workshop Held in October 1998. Online. Available At:

Http://www.Ctg.Albany.Edu/Resources/Abstract/Abdgfinalreport.Html. Accessed March $1,2001$.

5. Cook, J. and T. Wall. 1980. New Work Attitude Measure of Trust, Organizational Commitment and Personal Need Fulfillment. Journal of Occupational Psychology 53: 39-52.

6. Council for Excellence in Government. 2000. E-Government: The Next American Revolution. Available At: Http://www.Excelgov.Org. Accessed March 2001.

7. Creed, W. E. and R. E. Miles. 1996. Trust In Organizations: A Conceptual Framework Linking Organizational Forms, Managerial Philosophies, And The Opportunity Costs Of Controls. In Kramer, R. M. \& Tyler, T. R. (Ed.), Trust In Organizations: Frontiers Of Theory And Research, 16-38. Thousand Oaks, CA: Sage.

8. Davenport, T., D. Delong, and M. Beers. 1998. Successful Knowledge Management Projects. Sloan Management Review 39(Winter): 43-57.

9. Davenport, T., S. Jarvenpaa, and M. Beers. 1996. Improving Knowledge Work Processes. Sloan Management Review 37(summer): 53-65.

10. Davenport, T., and L. Prusak. 1999. Working Knowledge: How Organizations Manage What They Know. Boston: Harvard Business School.

11. Davenport, T., and P. Klahr. 1998. Managing Customer Support Knowledge. California Management Review 40(3): 195-208.

12. Delong, D. 1997. Building The Knowledge-Based Organization: How Culture Drives Knowledge Behaviors. Working Paper, Ernst \& Young's Center for Business Innovation. Boston.

13. Duncan, R. 1972. Characteristics of Organizational Environments and Perceived Environmental Uncertainty. Administrative Science Quarterly 17(3): 313-327. 
14. Dyer, J. 1997. Effective Interfirm Collaboration: How Firms Minimize Transaction Costs And Maximize Transaction Value. Strategic Management Journal 18(7): 535-556.

15. Gang, E. 2002. Access to the Internet in Asia. Chosun Daily Newspaper in South Korea, July 24th. Available At

Http://www.Chosun.Co.Kr/W21data/Html/News/200207/200207240028.Html. Assessed July 2002.

16. Gold, A., A. Malhotra, and A. Segars. 2001. Knowledge Management: An

17. Organizational Capabilities Perspective. Journal of Management Information Systems 18(1): 185-214.

18. Grant, R. 1996. Toward Knowledge Based Theory Of The Firm. Strategic Management Journal 17(Winter): 109-122.

19. Greeves, R. 2000. The Penultimate Mile: Local And State Government Collaborating To Serve Citizens Through Information Technology, Council Of Excellence In Government. Available at Http://www.excelgov.org/techcon/. Accessed July 2002.

20. Hage, J. and M. Aiken. 1967. Relationship of Centralization to Other Structural Properties. Administrative Science Quarterly (June): 79-80.

21. Inkpen, A., and P. Beamish. 1997. Knowledge, Bargaining Power, And the Instability of International Joint Ventures. Academy Of Management Review 22(1): 177-202.

22. Kanter, R., B. Stein, and T. Jock. 1992. The Challenge Of Organizational Change: How Companies Experience It And Leaders Guide It. New York: The Free Press.

23. Kim, S. and D. Kim. 2003. South Korean Public Officials' Perceptions of Values, Failure, and Consequences of Failure in E-Government Leadership. Public Performance And Management Review 26(4): 360-375.

24. King, W. 1999. Integrating Knowledge Management Into IS Strategy. Information Systems Management 16(4): 70-72.

25. Leonard, D.1995. Wellsprings of Knowledge: Building and Sustaining the Source of Innovation. Boston: Harvard Business School Press.

26. Leonard, D., and S. Sensiper. 1998. The Role of Tacit Knowledge in Group Innovation. California Management Review 40(3): 112-132.

27. Mcdermott, R. A. 1999. Why Information Technology Inspired But Cannot Deliver Knowledge Management. California Management Review 41(4): 108.

28. Modesitt, C. 2002. Bridging the Gap between Citizens and Local Government with Information Technology: Concepts and Case Studies. National Civic League.

29. Nonaka, I., and H. Takeuchi. 1995. The Knowledge Creating Company: How Japanese Companies Create The Dynamics Of Innovation? New York: Oxford University Press.

30. O'Dell, C., and C. Grayson. 1998. If Only We Knew What We Know: Identification And Transfer Of Internal Best Practices. California Management Review 40(3): 154-174.

31. Quigley, E. J. and A. Debons. 1999. Interrogative Theory of Information and Knowledge, In Proceedings of SIGCPR '99, 4-10. New Orleans, LA.: ACM Press.

32. Ruggles, R. 1998. The State of the Notion: Knowledge Management in Practice, California Management Review 40(3).

33. Strover, S. and J.D. Straubhaar. 2000. Assessing Citizen Utilization of E-Government Services: A Survey of Issues and Attitudes in Texas. Government Finance Review 16 (5): 27.

34. Teece, D. 1998. Capturing Value from Knowledge Assets: The New Economy, Markets for Know-how and Intangible Assets. California Management Review 40(3): 55-79.

35. Teigland, R. 2000. Communities of Practice at an Internet Firm: Netovation vs. On-Time Performance. In Lesser, E. L., M.A. Fontaine and J.A. Slusher (Eds), Knowledge and Communities, 151-178. Butterworth Beinemann.

36. Thurow, L. C. 1999. Building Wealth: The New Rules for Individuals, Companies, and Nations in a Knowledge-Based Economy, Harper Business.

37. United Nations and American Society for Public Administration. 2001. Global Survey of E-Government. Available At Http://www.Unpan.Org/Egovernment2.Asp. Accessed December 2002. 
38. Von Krogh, G. 1998. Care in Knowledge Creation. California Management Review 40(3): 133-153.

39. Wenger, E. 1999. Knowledge Directions, the Journal of the Institute for Knowledge Management 1(fall): 48-63.

\section{Appendix: Survey Items}

*Items were measured on a seven-point frequency of usage, with 1 for "almost never use" and 7 for "almost always use," all other items were measured on a seven-point Likert-type scale, with 1 for "strongly disagree" and 7 for "strongly agree"

\section{Organizational culture}

Visions and Goals

1. My organization has future oriented organizational visions.

2. Top management leaders present clear organizational vision and communicate it with employees.

3. Overall, organizational vision and goals are clearly stated in this agency.

4. Employees in this agency understand organizational vision and goals.

5. Every employee in this agency can explain organizational vision and goals to others.

\section{Trust}

1. Employees have full confidence in the skills of their co-workers.

2. Employees trust expertise of their co-workers.

3. If employees got into difficulties at work, they know their co-workers would try and help them out.

4. Employees do not try to deceive their co-workers for their own profits.

Social networks

1. Employees communicate with each other through informal meetings within the organization.

2. Employees interact and communicate with other people or groups outside the organization.

3. Employees actively participate in communities of practice, which are voluntary forums of employees around a topic of interest.

\section{Organizational structure}

\section{Centralization}

1. Employees participate in the decision on the adoption of new policies or programs.

2. There can be little action taken here until a supervisor approves a decision.

3. A person who wants to make his or her own decision without consulting his or her supervisors would be quickly discouraged here.

4. Even small matters have to be referred to someone higher up for a final answer. 
5. Any decision I make has to have my boss's approval.

6. Formalization

7. Each unit of this agency has well-established formal rules, task guidelines, and operational procedures.

8. There are many rules on the job.

9. Employees are constantly being checked on for rule violation.

10.Employees always carry out their tasks by rules and formal documents in organization.

11.Employees feel as though they are constantly being watched to see that they obey all the rules.

Performance-based reward systems

1. Individual or team-based performance is measured with fair.

2. This organization provides me with a fair opportunity for advancement or promotion.

3. Employees believe that they are promoted to a higher grade not by years of work but by their competencies and performance.

4. Pay increase or bonus is the most important factor affecting job commitment.

5. I am satisfied with the amount of pay and reward I receive.

6. Reward system affects employees' knowledge transferring, sharing and utilizing.

\section{Information technology application}

Application*

1. Employees' utilization of Internet, e-mail, electronic bulletin boards.

2. Employees' utilization of Intranet

3. Employees' utilization of DB (database), EDMS (electronic data management system)

4. Employees' utilization of KMS(Knowledge Management System)

End-User Focus

1. Information systems and software in this agency are designed to be user friendly.

2. It is easy for me to use information systems without extra training.

Knowledge Sharing Activities

1. Employees voluntarily share individual know-how, effective information and knowledge with each other.

2. Employees can freely access to the majority of document, information and knowledge within organization.

3. Employees cooperate or communicate with each other teams or groups for sharing information and knowledge. 